\title{
PREFACE TO THE SPECIAL ISSUE ON THE \\ 250TH ANNIVERSARY OF RUTGERS UNIVERSITY PART TWO: FROM THE REVOLUTIONARY WAR TO THE 21ST CENTURY
}

\author{
BY ROBERT G. SEWELL, EDITOR \\ rgsewell@libraries.rutgers.edu
}

In Part Two of this special issue on the 250th anniversary of Rutgers University, we continue David J. Fowler's meticulously researched biography "Benevolent Patriot: The Life and Times of Henry Rutgers." In Part One of this special issue, Fowler first presented a general introduction to Henry Rutgers' life. He then further explored Rutgers" ancestors and early years in "Benevolent Patriot: The Life and Times of Henry Rutgers-Part One: 1636-1776." Here, Fowler presents parts two and three of his series of biographical articles: "I Have Bestowed My Mite': The Revolutionary War Years" and "Back Home, 1783-1800." The other articles in this part of the special issue focus on Rutgers in the 20th and 21st centuries: Paul G. E. Clemens and Carla Yanni's "The Early Years of Livingston College, 1964-1973: Revisiting the 'College of Good Intentions'," and Matthew Knoblauch's "The Scarlet Beat: The Evolution of Law Enforcement at Rutgers." It is important to note the connections among three of the authors. Professor Clemens has been a mentor to both Fowler and Knoblauch. He served as Fowler's dissertation advisor and taught the class for which Knoblauch initially wrote about law enforcement at Rutgers.

In Fowler's article on the Revolutionary War years, it is revealed that Rutgers had only a few months of combat. During one of the first battles of the war, his impetuous younger brother, Harman, was killed. He soon took on a more bureaucratic function first as deputy muster master of the army and later the department head. His duties involved collecting information about supplies and troops and where to deploy them. While not a glamorous job compared to the actual combat experience, he made excellent connections that helped him after the war. He also received the rank

http://dx.doi.org/10.14713/jrul.v68i2.1984

The Journal of the Rutgers University Libraries, Volume 68, Issue 2, pp. iii-v. 
of colonel at the end of the war. Throughout the war, the British occupied New York City and took control of the Rutgers Farm, which was considered the most valuable property in the city. While the buildings and crops were despoiled, they were not demolished. With good political and societal connections made during the war and a home with extensive land, Henry, the patriarch of the Rutgers family, was in a position to reestablish this family wealth.

In part three of Fowler's biography, "Back Home, 1783-1800," we follow Rutgers' involvement in the religious, business, and political spheres of New York. One aspect of Rutgers' life discussed in this article will be of considerable interest-the fact that he owned several slaves. Fowler delicately places this in the context of the times and the Dutch Reform position on slavery and attitude towards nonwhite people in general. He was known, however, as a benevolent patriot in his times because of his philanthropy and dedication to his community and the new nation. Fowler's narrative ends at the beginning of the 19th century, but Rutgers lived until 1830 and became a generous donor to religious and educational institutions. Fowler has made a major contribution to our understanding of Rutgers' life and times. His research on Rutgers' life was supported by members of the Rutgers community including Nicholas and Nancy Rutgers, Barry Kramer, and Bob Mortensen, and by the Rutgers Foundation and its former director of leadership gifts, John Pearson.

Moving into the 20th century, the next article explores the early years of Livingston College (1964-1973). Paul G. E. Clemens, a history professor at Rutgers, and Carla Yanni, who has a joint appointment in Rutgers' history and art history departments, disclose the detailed planning that took place between 1964 and 1969 for the "College of Good Intentions." Livingston was conceived to reflect new ideas in higher education, emphasizing closer relationships between faculty and students-even in governance and curriculum development—serving, among others, underrepresented populations in U.S. colleges; and investigating academic problems in an interdisciplinary fashion with relevance to contemporary life. Following these concepts, architectural plans were drawn to facilitate such interactions.

The opening of the college in September 1969 and the first few years thereafter, however, were characterized by the primary planner and first dean of the college, Ernest Lynton, as "chaos and confusion." The college was plagued by underfunding- 
construction of new buildings was barely begun and library and health services were extremely limited compared to Rutgers and Douglass colleges. Bringing together different ethnic groups brought about clashes emphasizing identity politics. Some criminal activities took place on campus, but the most extreme troubles of the first two years were over by the third. Livingston remained a dissident center of Rutgers college life, critical of the more traditional colleges, making, on balance, significant changes in academic and student life. Lynton's ideas, such as internships, interdisciplinary approaches to problems, and community service have become a part of modern public research universities.

Matthew Knoblauch's article, "The Scarlet Beat: The Evolution of Law Enforcement at Rutgers," traces the development of Rutgers University Police Department (RUPD) from a parking authority into a campus security force. He describes this evolution from the early 1960 s into the 21 st century evaluating the professionalization of the department, the officers of the Campus Patrol/RUPD and their retention rate, the administrative structure, the evolution of officers' uniforms, and, ultimately, the acquisition of firearms. Knoblauch also discusses the changing concept of in loco parentis at universities and the implications for campus policing.

This two-part special issue of the Journal joins the celebration of the 250th anniversary of Rutgers that the university is carrying out during 2016. We hope it is also a lasting contribution to the history of the university. As my annotated bibliography in Part One, "Rutgers History in the Journal of the Rutgers University Libraries: An Annotated Bibliography" (http://jrul.libraries.rutgers.edu/ index.php/jrul/article/view/1957) demonstrates, this journal is an important source of information on the long and complicated history of the institution, from the small, colonial Queen's College to the major public university Rutgers is today. 